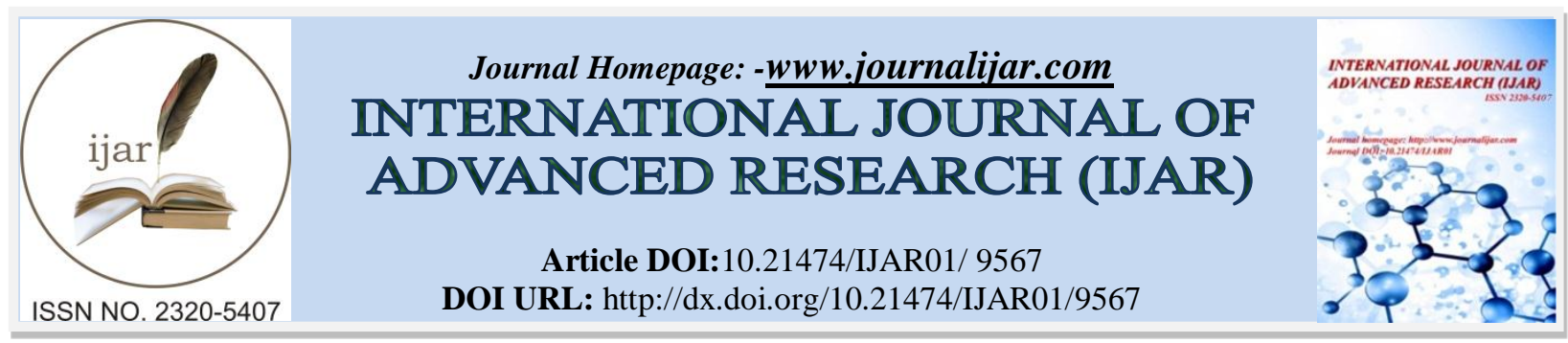

RESEARCH ARTICLE

\title{
ON THE DALLOL BOSSO WATER QUALITY: A CASE STUDY OF THE FILINGUÉ AND BALLAYARA DEPARTEMENTS GROUNDWATER.
}

Hama Adamou, Abdou Salam Manzola, Haoua Amadou and Mahaman Sani laouali.

Laboratoire de Chimie de l'eau, Faculté des Sciences et Techniques, Université Abdou Moumouni de Niamey, BP 10662 Niamey, Niger.

\section{Manuscript Info}

Manuscript History

Received: 12 June 2019

Final Accepted: 14 July 2019

Published: August 2019

Key words:-

Quality, Water, Groundwater, Dallol

Bosso, Ballayara, Filingué.

\section{Abstract}

The main objective of our study is to improve knowledge on the quality of groundwater in the Dallol Bosso area, particularly in the departments of Filingué and Balayara (Tillabéry Region).

Thirty-six (36) samples were taken from eighteen (18) water points in three (03) municipalities in these departments. Seventeen (17) physicochemical and two (02) bacteriological parameters were analyzed, on site and in the laboratory. The so-called GOD method was used for water vulnerability assessment.

The analyzed waters have an acidic $\mathrm{pH}$ with a neutral tendency in places, between 5 and 7.6. They are weakly mineralized with an electrical conductivity varying from $48.2 \mu \mathrm{S} / \mathrm{cm}$ to $735 \mu \mathrm{S} / \mathrm{cm}$. The result of these analyzes show that the physico-chemical quality of the waters is acceptable. However, $83.3 \%$ of the water points in the study area are polluted with nitrates due to a probable influence of human activities. $33.3 \%$ of the samples analyzed contain a nitrate concentration above the maximum limit of $50 \mathrm{mg} / \mathrm{L}$ set by the WHO. The main source of mineralization in the waters of the study area is natural, with local anthropogenic inputs of nitrates and potassium. The results of the bacteriological analyzes revealed a large proliferation of bacteria indicative of contamination of faecal origin (Total and Faecal Coliforms).

From a physico-chemical point of view, the quality of the waters in our study area is acceptable, but it is bacteriologically unfit for human consumption without prior treatment. These analyzed waters belong to $66.7 \%$ of the class (excellent for irrigation) and $33.3 \%$ of the class (good for irrigation).

It appears that the groundwater table is vulnerable to pollution of all kinds throughout the study area. The degree of vulnerability varies from low to high and moderate. Thus, moderate vulnerability occupies $44.4 \%$, the other two (low and high) each occupy $27.8 \%$.

Copy Right, IJAR, 2019,. All rights reserved. 


\section{Introduction:-}

The increase in population and the development of urban areas, industrial units and cultivated land have resulted in a deterioration in groundwater quality and a very significant decrease in reserves, which sometimes represent the only water resources available to feed the populations (Baali, 2001).

This problem of groundwater quality arises in Niger from two aspects: bacteriological and physico-chemical. With regard to the bacteriological aspect, there have been outbreaks of waterborne diseases (cholera, typhoid fever, diarrhea, Guinea worm), which are mainly the cause of infant mortality (Ministère, 2013).

With regard to the physico-chemical aspect, high contents of fluorides have been found in some localities of the country, such as Tibiri (Maradi region) and Koundoumawa Miriah (Zinder region) with respectively (6 to $6.9 \mathrm{mg} / \mathrm{l}$ and 2.62 to $5.25 \mathrm{mg} / \mathrm{l}$ ), (Ministère, 2013). Nitrate pollution is increasing in the areas of the river and Dallol with levels often exceeding WHO guidelines.

Indeed, in these areas, agriculture and livestock farming are generally the main activities of the population. The risk of pollution by nutrients in general and nitrates in particular threatens the water resource. This risk is even greater in an area characterized by the absence of a protective cover, leading to direct contact between tank formations and pollutants (Baali, 2001).

The specific aim is to analyze the physico-chemical and bacteriological parameters of these waters, to determine their suitability for human consumption and the level of vulnerability of the slick.

\section{Materials And Methods:-}

\section{Presentation of the Dallol Bosso}

The Dallol Bosso is a dry valley of a former tributary of the River Niger, 10 to $20 \mathrm{~km}$ wide, stretching $330 \mathrm{~km}$ from north to south in the regions of Tillabéri and Dosso, between Mali and Benin. It covers about 40,000 $\mathrm{km}^{2}$, The average altitude increases from $249 \mathrm{~m}$ to $175 \mathrm{~m}$ from north to south of the Dallol.

The climate is sub-desert in the North (rainfall $330 \mathrm{~mm}$ ), Sudanian in the extreme South $(780 \mathrm{~mm}$ ) and Sahelian in the central part (.Paquier et al, 1985). Flow is currently limited to the rainy season (Boukari, 1993). The surface water tables and permanent ponds in the southern part make it a suitable region for agriculture, livestock and fishing (Dallol Bosso, 2017).

In the Dallols, the groundwater table is confused with alluvial groundwater. The lower and middle groundwater tables are mainly recharged through the groundwater table. The latter is supplied by direct infiltration of rainwater and especially by run off in endorheic areas favourable to the accumulation of water in ponds, where it undergoes significant seasonal and interannual fluctuations.

Our study concerned three (03) municipalities in the departments of Filingue and Ballayara. These are the rural municipalities of Tondikandia and Imanan (Fillingué department) and the rural municipality of Tagazar (Ballayara department). The study area covers an area of approximately $4215.38 \mathrm{~km} 2$, between $13.528^{\circ}$ and $14.298^{\circ}$ North Latitude, and between $2.562^{\circ}$ and $3.548^{\circ}$ East Longitude (Figure 1).

The socio-economic activities of the area are mainly focused on agriculture and livestock. All three municipalities are crossed by the Dallol Bosso, making the study area one of the most favourable areas for the development of market gardening in Niger. Indeed, the groundwater table (CT3 and alluvium) is easily accessible by well and borehole, especially in the lowlands where it is almost flush. This has encouraged the proliferation of a multitude of market gardening and mixed-use hydraulic structures in and around the lowlands, next to dwellings and on sites.

The relief of the study area is composed of seven (07) systems: the alluvial system, the plateaus, the slopes, the glacis, the wind system, the closed depressions and others (residual mounds, snags, collinettes, small pools). The most dominant are the plateaus, the alluvial system, the glacis and the slopes and the order of dominance varies from one municipality to another. 
The soils in the study area differ according to the relief, but the most common are the loose soils of valleys and dunes, the clay soils of lowlands, the encrusted soils with sandy-clay veneers of plateaus, glazes and slopes (SOGETHA, 1962).

Most of the soils of the Dallol come from reworked wind formations and belong to the subclass of tropical ferruginous soils. Their texture is sandy on the surface; the clay content does not exceed 5\% while the sand content is always between $90 \%$ and $97 \%$. Their texture is poor, which favours the erosive action of the wind (SOGETHA, 1962).

\section{Hydrography:}

The most important component of the current hydrography of the study area is represented by the Dallol Bosso and its ponds, although the flow is no longer permanent.

This valley no longer has a permanent flow and its hydrographic system is severely degraded: upstream of Ballayara, the valley is increasingly invaded by recent sand dunes, and downstream, in the rainy season, there are no longer any well-defined watercourses; but a string of ponds episodically linked by divagant flows (Karbo et al 1992).

\section{Hydrogeological framework of the Dallol Bosso area:}

The region's groundwater resources are located in the valley's alluvial formations and in the underlying sedimentary formations of the Continental Terminal and the Hamadian Continental (Armand, 1987).

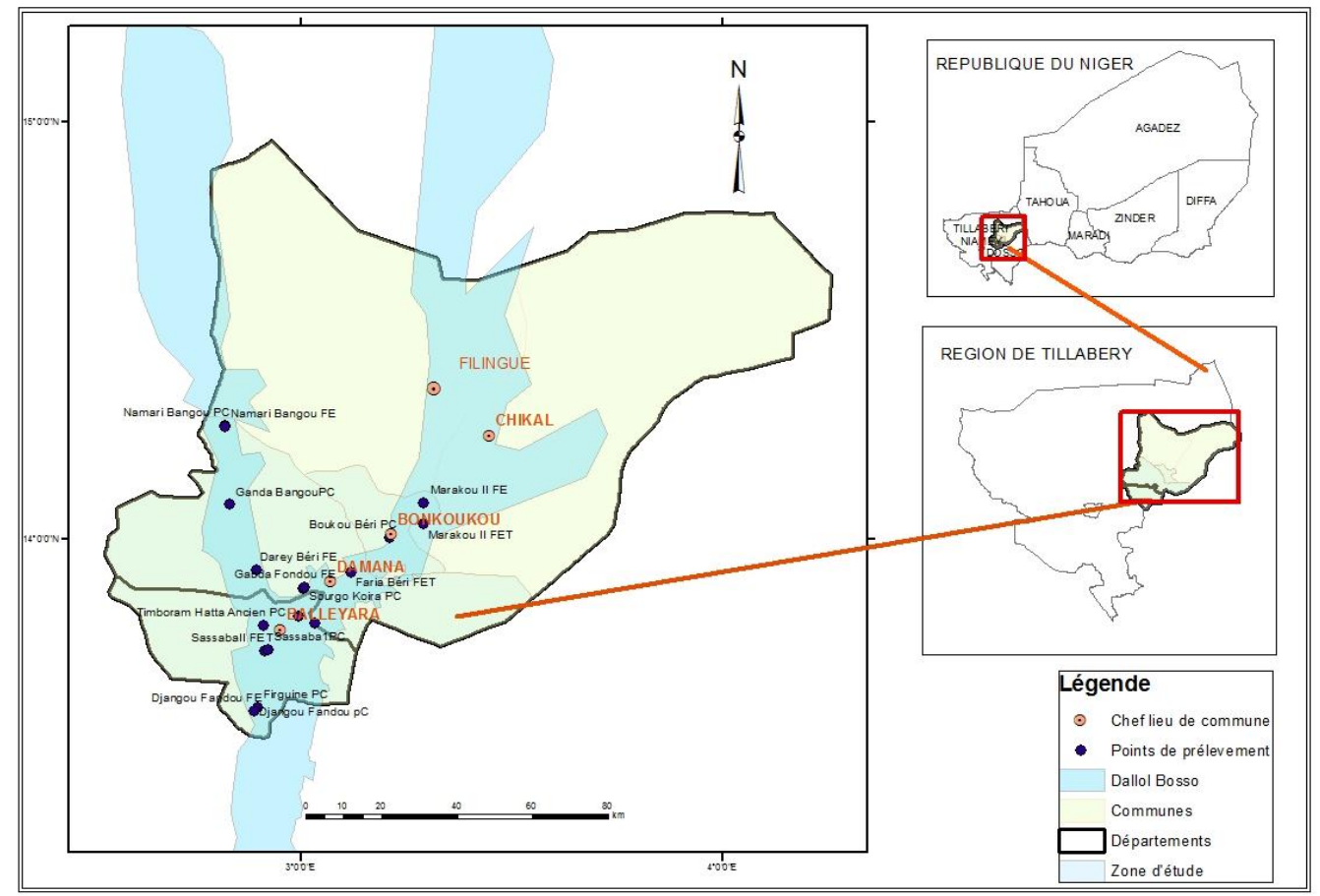

Figure 1:-Presentation of the study area

\section{Methodology:-}

To achieve the objectives of our study, we adopted a methodology whose different steps are: sampling; physicochemical and bacteriological analyzes and data processing.

Water samples were collected from eighteen (18) water points including nine (09) cemented wells, four (04) auger boreholes and five (05) village mechanical boreholes, in three (03) communes including two (02) of the department of Fillingué (Imanan and Tondikandja) and one (01) of the department of Ballayara (Tagazar). 
The physical parameters, namely $\mathrm{pH}$, temperature, conductivity and turbidity, were measured in situ using a $\mathrm{pH}$ meter, a portable colorimeter covering wavelengths from 400 to 800 nanometers equipped with a tungsten filament lamp, a WTW 330 conductivity meter and a Hach 2100 Q portable turbidimeter.

For physico-chemical and bacteriological analyzes, parameters were measured on site. Conventional sampling methods were used. The collected samples were then labeled and placed in a temperature-controlled cooler at about $4^{\circ} \mathrm{C}$ and taken to the Water Quality Control Laboratory of the Regional Directorate of Hydraulics and Sanitation of Tillabéri for analysis. The traditional analytical methods recommended by the French AFNOR standards were used on the water samples collected:

-The volumetric method to determine: hardness, calcium, magnesium, complete alkalimetric title and bicarbonates. The molecular absorption spectrometry used in this study is the colorimetric method whose elements determined by this method are sulfates, nitrates, nitrites, fluorides, chlorides and total iron. -The Flame Emission Spectrometry (or flame photometry) used to determine potassium and sodium. -Membrane filtration technique followed by incubation and counting, for bacteriological parameters (total coliforms and fecal coliforms).

\section{Data processing:}

For the reliability of the analytical results, we applied the ion balance method or a maximum error of $6 \%$ was accepted. This ionic balance is calculated by the following formula: (Ionic Balance (BI) in $\%)=[\Sigma($ cations in $\%)$ $\Sigma$ (anions in \%)] / [ $\Sigma$ (cations in \%) $+\Sigma$ (anions in \%)]. The values of the measured parameters were compared with the WHO guidelines for quality control of water intended for human consumption. This comparison makes it possible to determine the physico-chemical and bacteriological quality of the water studied in order to demonstrate its suitability for human consumption. To determine the irrigation suitability of the water in the study area, we classified it using the Riverside Laboratory method. This method is based on electrical conductivity and sodium absorption rate or Sodium Absorption Rate (S.A.R.). We have S.A.R=, with, and expressed in meq/L.

The combination of these two criteria (conductivity and S.A.R.) makes it possible to define the different classes of water suitability for irrigation.

The vulnerability assessment of the waters in our study area was determined by the method known as GOD (Groundwater Over all aquifer Depth to water table).

\section{Results And Discussion:-}

In this study, three types of results are presented piezometric measurements, physico-chemical analyzes and bacteriological analyzes.

\section{Piezometric measurements:}

The results of piezometric measurements carried out on site show that the static levels of most cemented and auger drilled (FET) wells vary from 2.42 to less than $16 \mathrm{~m}$, and depths from 4 to $27 \mathrm{~m}$. The deepest (only 2 wells) have static levels of $27.9 \mathrm{~m}$ and $28.9 \mathrm{~m}$ with depths of $32 \mathrm{~m}$ each. There are $5 \mathrm{FE}$ village boreholes with static levels ranging from 9.5 to $20 \mathrm{~m}$ and depths from 64.16 to $86.7 \mathrm{~m}$.

\section{Results of the physical parameters:}

The physical parameters measured on site are: Hydrogen potential $(\mathrm{pH})$, temperature $\left(\mathrm{T}^{\circ}\right)$, electrical conductivity (EC), TDS and turbidity (Turb.). The statistics of these parameters have been presented in Table 1.

\begin{tabular}{|l|l|l|l|l|l|l|l|l|}
\hline Parameters & Unit & $\begin{array}{l}\text { WHO } \\
\text { Guidelines }\end{array}$ & Mean & Median & E-type & Variance & Min & Maxi \\
\hline $\mathrm{pH}$ & $\mathrm{U}$ & $6.5-8.5$ & 6.2800 & 6.4500 & 0.71 & 0.50 & 5.00 & 7.60 \\
\hline $\mathrm{T}$ & ${ }^{\circ} \mathrm{C}$ & - & 31.36 & 31.45 & 1.21 & 1.46 & 28.50 & 32.70 \\
\hline CE & $\mu \mathrm{s} / \mathrm{cm}$ & - & 249.6 & 215 & 214.5 & 25947.5 & 48 & 735 \\
\hline TDS & $\mathrm{mg} / \mathrm{l}$ & - & 124.6 & 107 & 80.46 & 6473.88 & 24 & 367 \\
\hline Turb. & $\mathrm{UNT}$ & 5 & 2.82 & 1.39 & 3.66 & 13.42 & 0.3 & 12.5 \\
\hline
\end{tabular}




\section{Hydrogen Potential (pH):}

The $\mathrm{pH}$ values measured in our study area range from 5 (Djongou Fandou, FE) to a maximum of 7.6 (Timboran, Hatta PC), with an average of 6.28 and a median value of 6.45. Of the 18 samples analyzed, 14 have an acidic character between 5 and 6.7, i.e. $77.8 \%, 3$ are slightly neutral or neutral in tendency and only 1 basic (Figure 2). We can therefore consider that these waters have an acid $\mathrm{pH}$ with a neutral trend in places (Figure 3). However, it should be noted that basic pH values of 7.6 and 7.52 were found by Amadou et al (2014) in the wells of the Dallol Bosso, respectively in Sandiré and Bonkoukou. The acidity of these waters is due to their origin (rainwater by direct infiltration and runoff) on the one hand, but also to the nature of the reservoir. Indeed, according to Beauchamp (2006), $\mathrm{pH}$ is acidic in waters of sandy or granitic aquifers. This acidity of the waters in the study area may also be due to the decomposition of organic matter. According to Matini et al (2009), the mineralization of organic matter in the soil, under the action of oxygen, releases carbon dioxide, which dissolves in water to form carbonic acid.

This $\mathrm{pH}$ range ( 5 to $6.7, \mathrm{n}=14$ ) and the mean and median values (6.28 and 6.45 respectively, $\mathrm{n}=18)$ are in agreement with the conclusions of Guéro (2003) which would place the $\mathrm{pH}$ representative of the groundwater table on the southwestern edge of the Iullemmeden Basin between 4.5 and 6.5. Indeed, 50\% (i.e. 09 samples) of the water analyzed has a $\mathrm{pH}$ in accordance with the WHO guidelines in force (6.5 to 8.5$)$, and the others (50\%) have a pH below 6.5, which does not pose any direct danger to human health. However, a pH below 6.5 can promote corrosion of pipes and plumbing fittings, resulting in an increase in the concentration of these metals in drinking water. This can have a harmful effect on health (Brunswick, 2017).

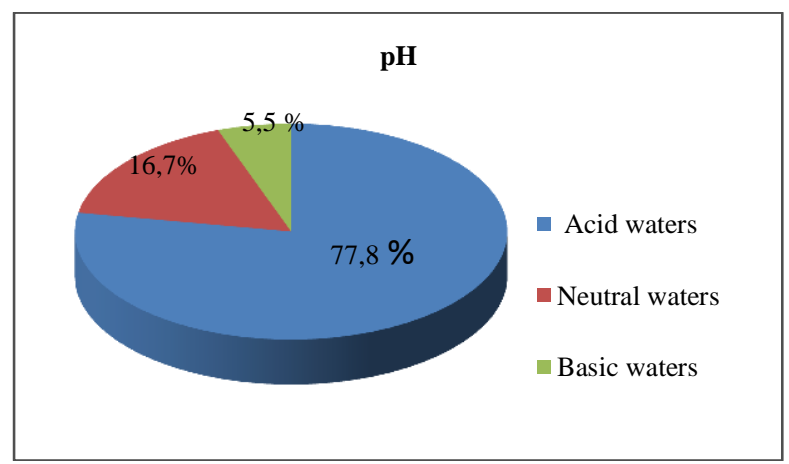

Figure 2:-Water distribution according to $\mathrm{pH}$

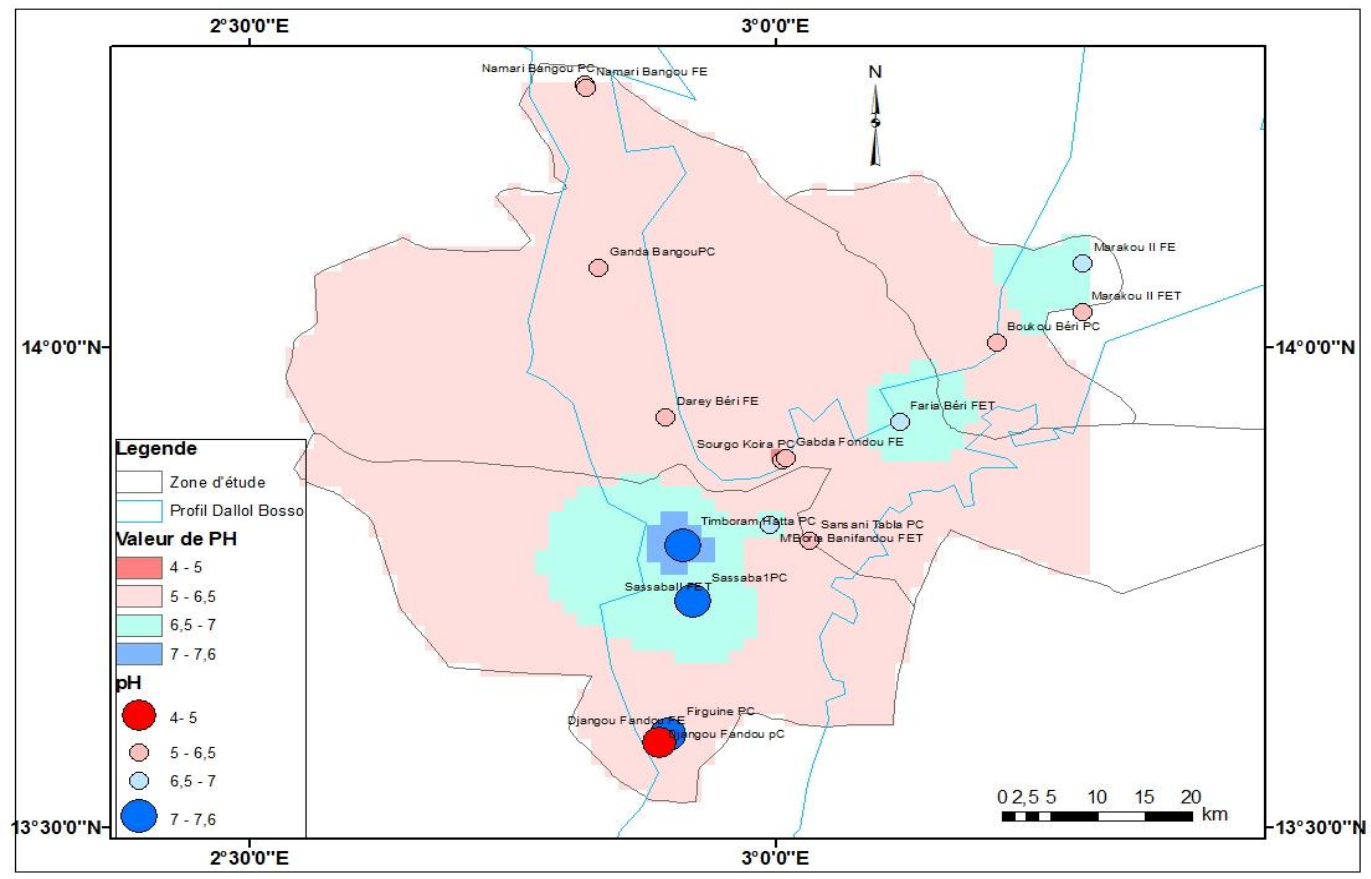

Figure 3:-pH map of the waters in the study area. 


\section{Temperature}

Water temperature is an important factor in the aquatic environment because it regulates almost all physical, chemical and biological reactions (Nordine et al, 2015; Chapman et al, 1996).

In our study area, the recorded temperatures range from $28.5^{\circ} \mathrm{C}$ (at Sassaba I PC) to $32.7^{\circ} \mathrm{C}$ (at Djongou Fandou $\mathrm{FE}$ ), with an average of $31.36^{\circ} \mathrm{C}$ and a median of $31.45^{\circ} \mathrm{C}$. These mean and median values are comparable to those found by Guéro (2003) (respectively $31.6^{\circ}$ and $31.7^{\circ}$ ) in the boreholes of the TC free groundwater of the southwestern edge of the Iullemmeden Basin. The average found in the wells $(n=9)$ is $30.6^{\circ} \mathrm{C}$, which is in agreement with that of $30.6^{\circ} \mathrm{C}$ found by Favreau (2000), in the area at Dantiandou and that of $29.48^{\circ} \mathrm{C}$ ( $\mathrm{n}=16$ ) measured by Ousseyni (2016) in the alluvial groundwater of the Dallol Bosso in the departments of Birni N'Gaouré and Falmey. However, it remains well below the average value of $25^{\circ} \mathrm{C}(\mathrm{n}=9)$ measured by Hamadou (2014) in the alluvial groundwater wells around the rural commune of Tagazar. In the boreholes, this average value is $31.85^{\circ} \mathrm{C}$ for the $\mathrm{FE}$ type $(n=5)$ and $32.34^{\circ} \mathrm{C}$ for the FET type $(n=4)$. The temperature difference observed, even if it is small, is in agreement with the depth of the structures (high temperature for boreholes compared to low temperature for cemented wells). Most samples $(89 \%)$ have a temperature above $30^{\circ} \mathrm{C}$ that is close to either the median $\left(31.45^{\circ} \mathrm{C}\right)$ or the mean $\left(31.36^{\circ} \mathrm{C}\right)$ (Figures 4$)$. This proves that this temperature is moderately well distributed in space.

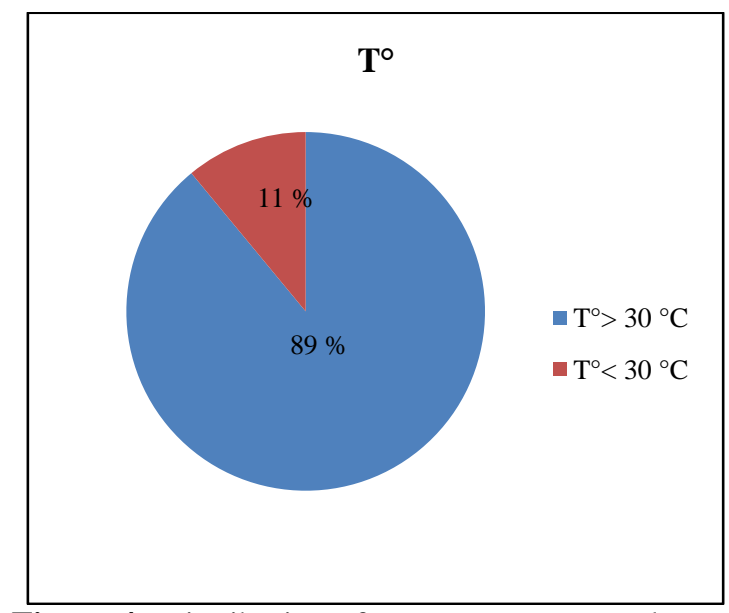

Figure 4:-Distribution of water temperature classes.

\section{III.1.3-Electrical conductivity (EC):}

The electrical conductivity of the study area varies from $48.2 \mu \mathrm{S} / \mathrm{cm}$, to Djongou Fandou, to $735 \mu \mathrm{S} / \mathrm{cm}$, to Timboran Hatta, for an average of $249.64 \mu \mathrm{S} / \mathrm{cm}$ and a median of $214.50 \mu \mathrm{S} / \mathrm{cm}$, proving that the waters of the study area are poorly mineralized, except the Timboran Hatta well which records the maximum value, followed by Marakou II FET with $418 \mu \mathrm{S} / \mathrm{cm}$. Similar values were found by Amadou et al (2014) in the wells of the Dallol Bosso $(256 \mu \mathrm{S} / \mathrm{cm}$ at Sandiré and $716 \mu \mathrm{S} / \mathrm{cm}$ at Bonkoukou). The overall median and mean values $(\mathrm{n}=18)$ of $214.50 \mu \mathrm{S} / \mathrm{cm}$ and 249.64 $\mu \mathrm{S} / \mathrm{cm}$ respectively are in agreement with the results of the study by Armand (1987). The latter concluded that the electrical conductivity of the groundwater of the Dallol Bosso is generally less than $250 \mu \mathrm{S} / \mathrm{cm}$. The results highlight that there is a great variability in conductivity in space and according to the types of structures. This is justified by its very high variance value (25947.5). The waters of FE boreholes are the least loaded, ranging from 48.2 to 137.12 $\mu \mathrm{S} / \mathrm{cm}$ via an average of $229 \mu \mathrm{S} / \mathrm{cm}, \mathrm{n}=5$ ). The most mineralized waters are those of PC and FET type structures, this is in accordance with the depth at which these waters are captured. In these types of structures, the water has a conductivity ranging from 110.7 to $735 \mu \mathrm{S} / \mathrm{cm}$ for an average value of $229.91 \mu \mathrm{S} / \mathrm{cm}$. The large variability in conductivity would be due to the nature of the field through which water flows during runoff before infiltration and during infiltration. Figure 5 shows that $11.1 \%$ of the samples analyzed have a conductivity of less than $100 \mu \mathrm{S} / \mathrm{cm}$, $55.6 \%$ between 100 and $250 \mu \mathrm{S} / \mathrm{cm}, 22.2 \%$ between 250 and $400 \mu \mathrm{S} / \mathrm{cm}$ and $11.1 \%$ between 400 and $750 \mu \mathrm{S} / \mathrm{cm}$ $(n=18)$. The most representative value for the electrical conductivity of groundwater in the study area would therefore be between 100 and $250 \mu \mathrm{S} / \mathrm{cm}$ (Figure 6). 


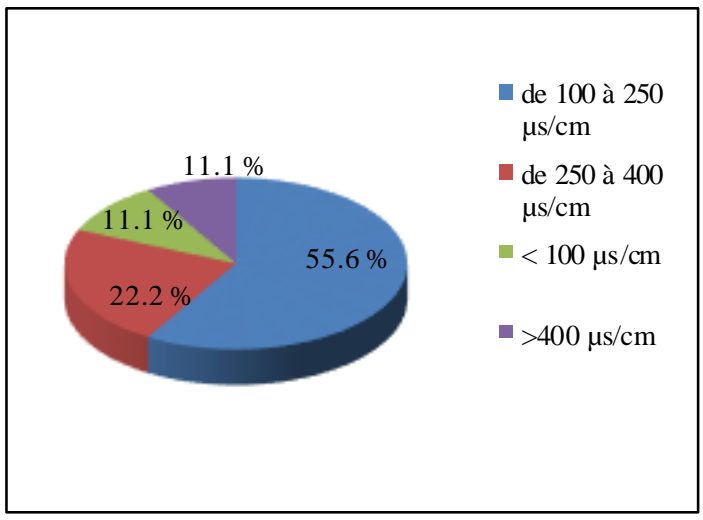

Figure 5:-Repartition of classes of conductivities

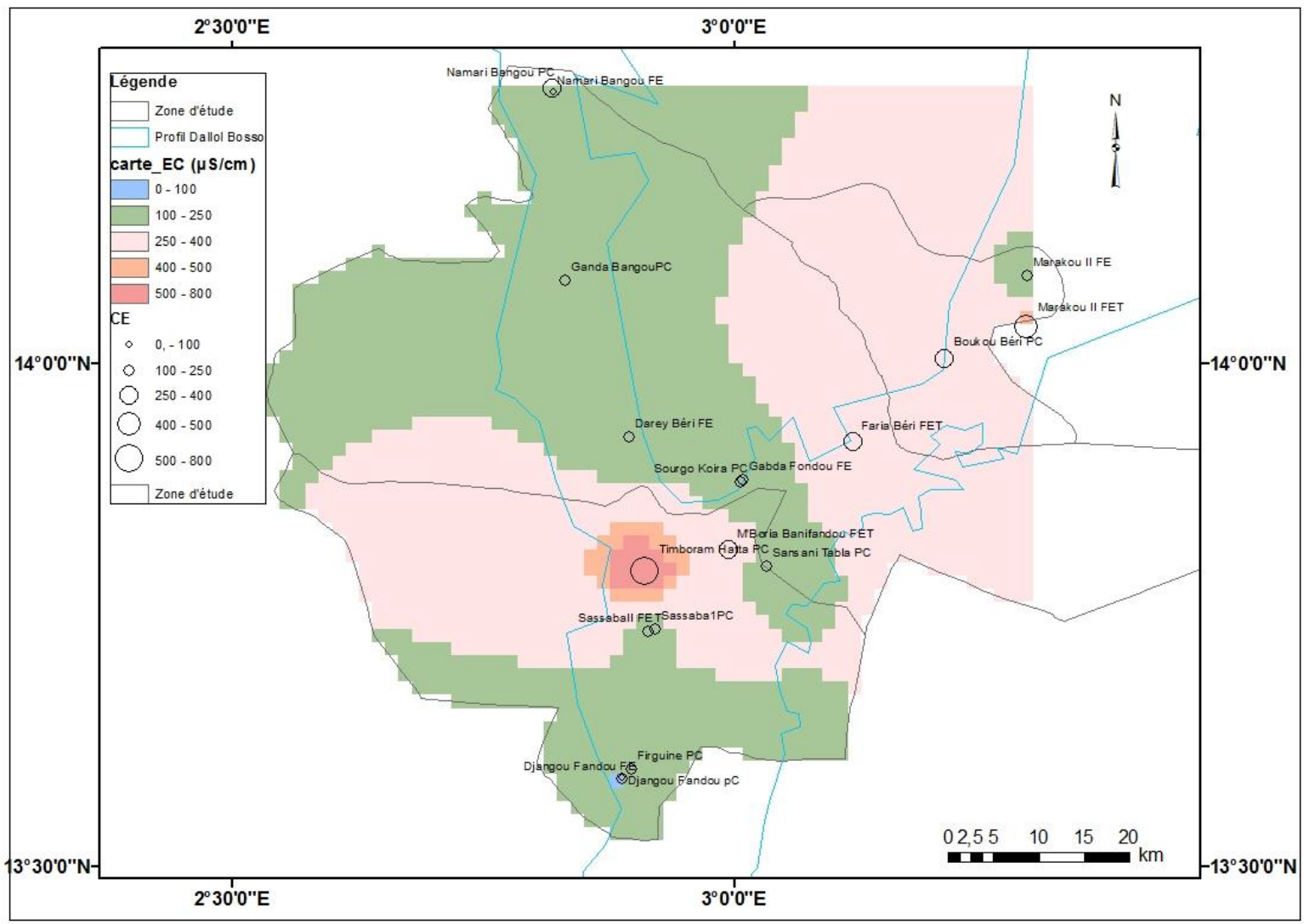

Figure 6:-Map of water connectivity of the study area.

\section{Turbidity:}

Turbidity of water in the study area ranges from 0.30 NTU (Djangou Fandou FE) to 12.48 NTU in Firgoune PC and the mean and median are 2.82 and 1.39 NTU respectively (Figure 7). All the water points sampled had turbidity values below 5 NTU (maximum value set by the WHO), except M'boria Banifandou and Firgune (12.4 and 12.5 NTU respectively), representing $89 \%$ compliance with WHO guidelines. 


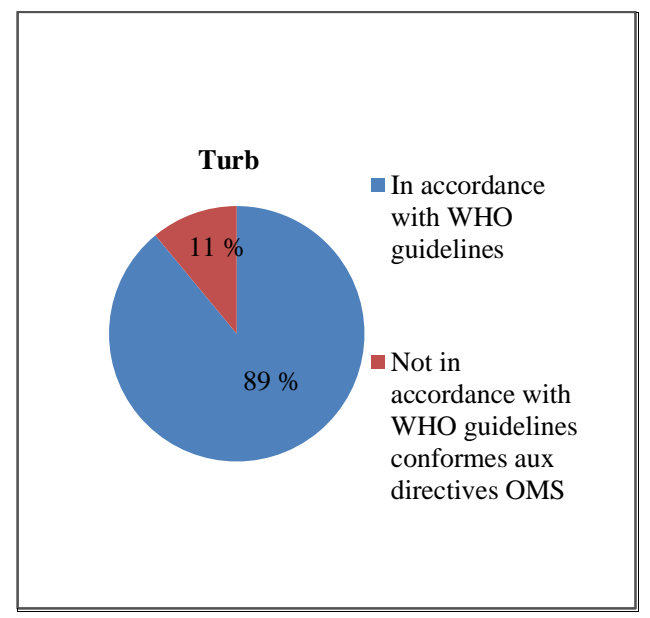

Figure 7:-Representation of graphic Turbidity

Chemical parameters Major cations:

Statistics on major cations are presented in Table 2.

Table 2:-Statistics of major cations ( $\mathrm{n}=18)$.

\begin{tabular}{|l|l|l|l|l|l|l|l|l|}
\hline Parameters & Unit & WHO Norms & Mean & Median & E-type & Variance & Min & Maxi \\
\hline $\mathrm{Ca}^{2+}$ & $\mathrm{mg} / \mathrm{l}$ & - & 11.68 & 8.4 & 8.2 & 67.3 & 1.6 & 36.4 \\
\hline $\mathrm{Mg}^{2+}$ & $\mathrm{mg} / \mathrm{l}$ & - & 4.11 & 3.22 & 3.72 & 13.84 & 0.61 & 14.1 \\
\hline $\mathrm{Na}^{+}$ & $\mathrm{mg} / \mathrm{l}$ & 200 & 16.03 & 14.4 & 11.89 & 141.44 & 2.8 & 50 \\
\hline $\mathrm{K}^{+}$ & $\mathrm{mg} / \mathrm{l}$ & 12 & 7.99 & 4.5 & 11.26 & 126.84 & 1.6 & 50 \\
\hline
\end{tabular}

Calcium, Magnesium, TH:

Calcium $(\mathrm{Ca})$ and magnesium $(\mathrm{Mg})$ are elements that are abundantly found in soil and rock and are essential to human health (Nouvelle-Écosse Environnement, 2008) and are essentially at the base of groundwater hardness. Calcium contents in the waters in our study area are low, ranging from $1.60 \mathrm{mg} / \mathrm{L}$ (at Namari Bangou, FE) to 36.40 $\mathrm{mg} / \mathrm{L}$ (at Timboram Hatta, PC), with an average value of $11.68 \mathrm{mg} / \mathrm{L}$ and a median of $8.40 \mathrm{mg} / \mathrm{L}$. The low calcium concentration indicates that these waters did not cross limestone or gypsum soils. The magnesium values obtained are also low and range from $0.61 \mathrm{mg} / \mathrm{l}$ (at Firgoune, PC) and $14.09 \mathrm{mg} / \mathrm{l}$ (at Timboram Hatta PC), with mean values of $4.11 \mathrm{mg} / \mathrm{l}$ and median values of $3.22 \mathrm{mg} / \mathrm{l}$. These low values of calcium and magnesium concentration are close to the results obtained by Ousseyni (2016) in the alluvial groundwater of the dallol Bosso, the Birni N'Gaouré Falmey area. They would be explained by the sandy nature of the soil in the study area. Indeed, calcium and magnesium would come from the hydrolysis of silicate minerals present in this soil (Matini, 2009).

The total hardness or Hydrotimetric Title (TH) of the analyzed waters varies from 10 to $149 \mathrm{mg} / \mathrm{l}$ of CaC through an average of $46.1 \mathrm{mg} / \mathrm{l}$ of $\mathrm{CaC}$. Knowing that $10 \mathrm{mg} / \mathrm{L}$ of CaC corresponds to $1^{\circ} \mathrm{F}$ (French degree), this total hardness varies from 1 to $14.9^{\circ} \mathrm{F}$ through an average of $4.61^{\circ} \mathrm{F}$ (Figure 8). Thirteen (13) waters analyzed, or $72.2 \%$, were very soft $\left(\mathrm{TH}<5^{\circ} \mathrm{F}\right)$; five (5), or $27.8 \%$, were soft $\left(5^{\circ} \mathrm{F}<\mathrm{TH}<20^{\circ} \mathrm{F}\right)$.

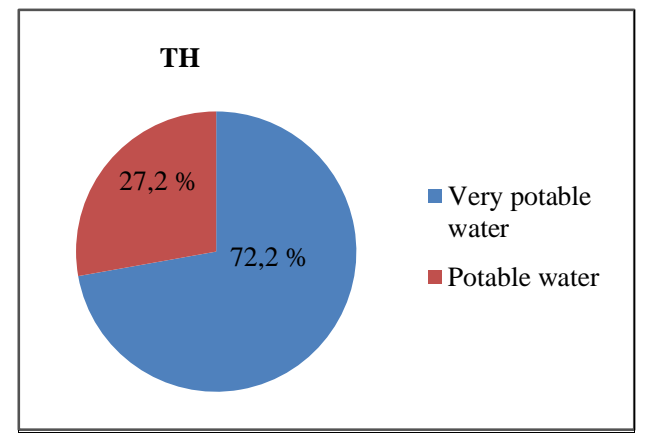

Figure 8:-Graphical representation of the THs of the water points 


\section{Sodium:}

In our study area, sodium has very variable values, ranging from very low values of $2.80 \mathrm{mg} / \mathrm{L}$ (at Djangou Fandou, FE) to a maximum value of $50 \mathrm{mg} / \mathrm{L}$ (at Faria Béri, FET) and average and median values of $16.03 \mathrm{mg} / 1 \mathrm{and} 14.40$ $\mathrm{mg} / \mathrm{l}$ respectively. All these values are below the maximum allowable concentration set by the WHO. $83.3 \%$ of the water points $(n=18)$ have a sodium content $<20 \mathrm{mg} / \mathrm{L}$ and $16.7 \%$ have a sodium concentration between 20 and 50 $\mathrm{mg} / \mathrm{L}$ (Figure 9). The origin of sodium in these waters would therefore be essentially natural with anthropogenic input in places.

\section{Potassium}

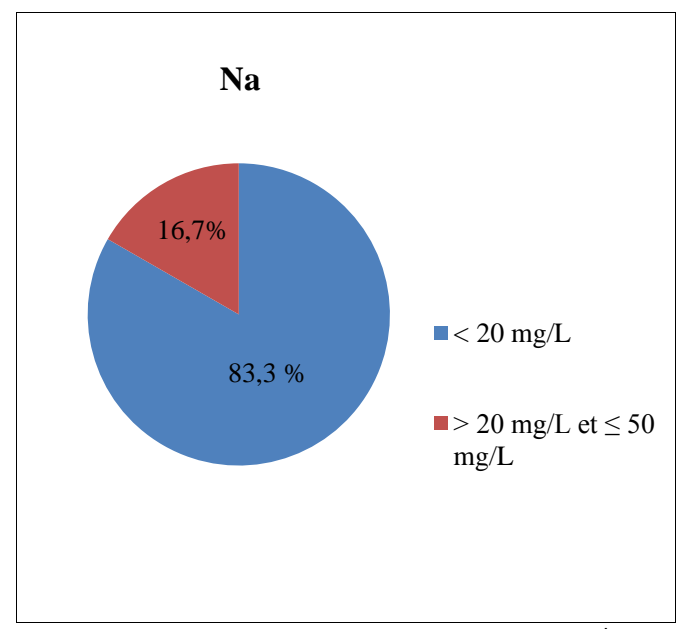

Potassium concentrations recorded in the study area vary widely from $1.6 \mathrm{mg} / \mathrm{l}$ (at Namari Bangou, PC) to a maximum of $50 \mathrm{mg} / \mathrm{l}$ (at Timboran Hatta, PC; the mean and median being $7.99 \mathrm{mg} / \mathrm{l}$ and $4.50 \mathrm{mg} / \mathrm{l} \mathrm{respectively).}$ Three water points $(16.7 \%$ ) contain levels greater than or equal to the maximum limit value of $12 \mathrm{mg} / \mathrm{L}$ set by the WHO, six (33.3\%) have values between 5 and $11 \mathrm{mg} / \mathrm{L}$ and nine $(50 \%)$ have levels below the median, ranging from 1.6 to $4 \mathrm{mg} / \mathrm{L}(\mathrm{n}=18)$ (Figure 10). This latter range appears to represent the potassium content of groundwater in our study area where anthropogenic input is negligible. High values (ranging from 12 to $50 \mathrm{mg} / \mathrm{L}$ ) were recorded in wells on the west branch side of the Dallol Bosso (Figure 11). The average level of $7.99 \mathrm{mg} / \mathrm{L}$ is in agreement with the $7.90 \mathrm{mg} / \mathrm{L}$ recorded by Ousseyni (2016) in the alluvial groundwater of the Dosso Bosso, Birni N'Gaouré Falmey area. However, it is more than twice the average value found by Moussa (2014) in the alluvial groundwater of the Maouri dallol and remains much lower than that recorded by Hamadou (2014). Indeed, the latter resulted in potassium contents ranging from 2.22 to $60 \mathrm{mg} / \mathrm{L}$ with an average of $26.3 \mathrm{mg} / \mathrm{L}(\mathrm{n}=9)$ in the wells of the alluvial groundwater table of the Dallol Bosso in the rural commune of Tagazar (Ballayara department). The presence of potassium in our study area would be mainly due to the erosion of potassium-containing minerals and the effect of evaporation where the groundwater is at shallow depths with anthropogenic leaching from soils containing potassium fertilizers (probably in the form of potassium nitrate). Potassium would therefore be of natural and anthropogenic origin in the waters of the study area. 


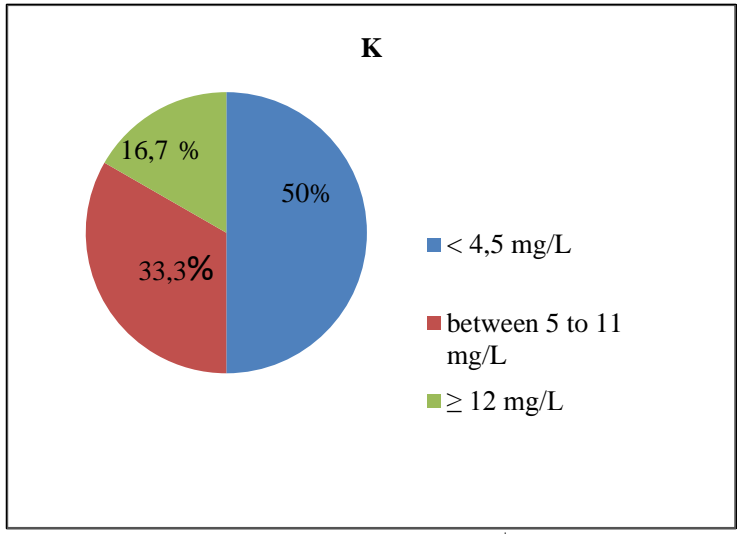

Figure 10:-Repartition of $\mathrm{K}^{+}$content

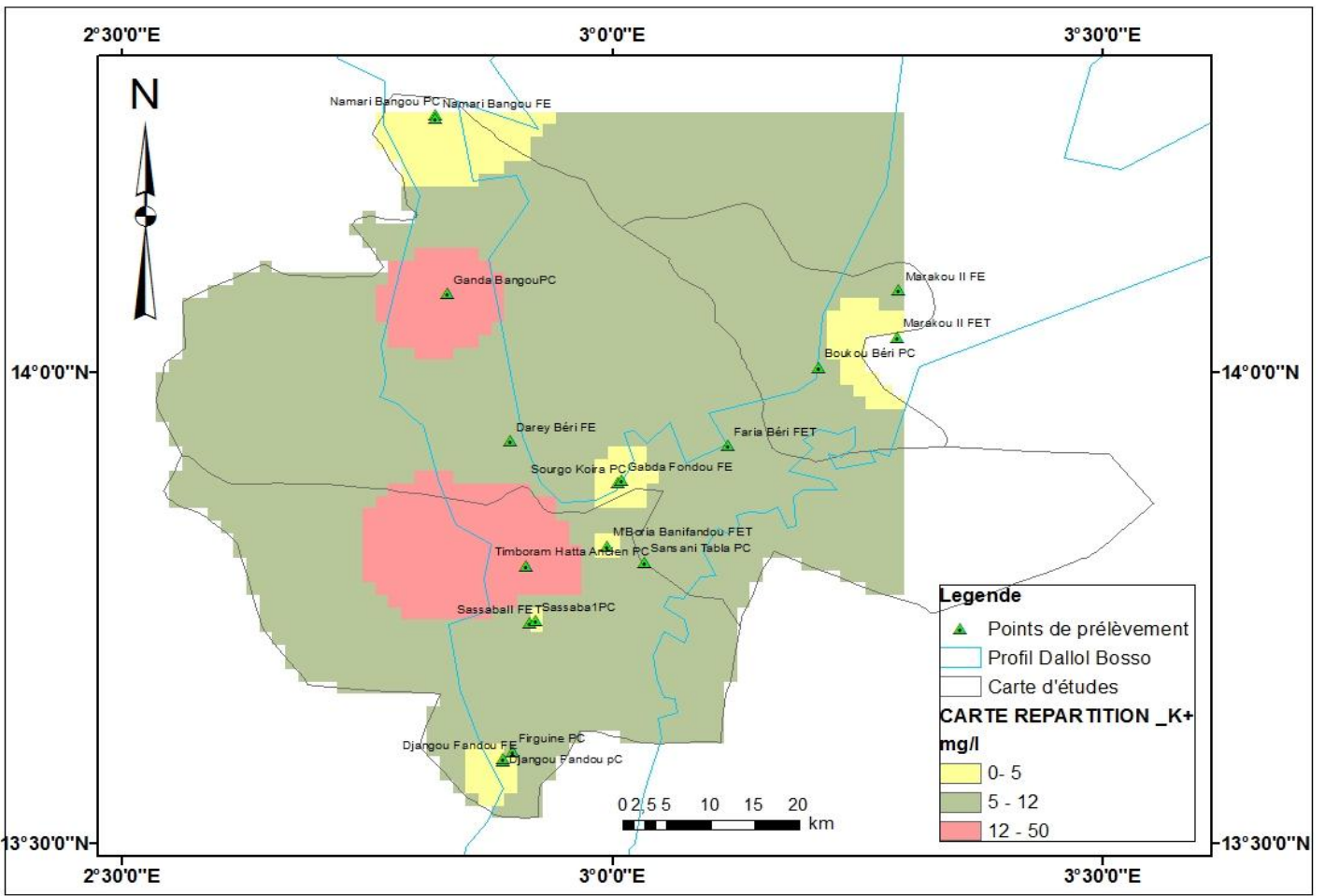

Figure 11:-Map of potassium content of water of the study area

Major Anions:

Statistics for major anions $(n=18)$ in our study area are presented in Table 3.

Table 3:-Statistics of major anions $(\mathrm{n}=18)$ :

\begin{tabular}{|l|l|l|l|l|l|l|l|l|}
\hline Parameters & Unit & $\begin{array}{l}\text { WHO } \\
\text { directives }\end{array}$ & Mean & Median & E-type & Variance & Min & Maxi \\
\hline SO4-- & $\mathrm{mg} / \mathrm{l}$ & 250 & 4.94 & 5 & 3.21 & 10.29 & 0 & 10 \\
\hline Cl- & $\mathrm{mg} / \mathrm{l}$ & 250 & 7.71 & 6.85 & 6.56 & 42.99 & 0.3 & 28.3 \\
\hline HCO3- & $\mathrm{mg} / \mathrm{l}$ & - & 42.16 & 27.76 & 42 & 1764.41 & 4.88 & 152.5 \\
\hline NO3- & $\mathrm{mg} / \mathrm{l}$ & 50 & 45.662 & 39.6 & 31.501 & 992.338 & 3.08 & 108.68 \\
\hline
\end{tabular}

\section{Sulphates:}

The sulphate contents recorded in the study area are very low and range from 0 to $10 \mathrm{mg} / \mathrm{l}$, with an average and median of $4.94 \mathrm{mg} / \mathrm{l}$ and $5 \mathrm{mg} / \mathrm{l}$ respectively. They therefore remain well below the WHO maximum limit 
$(500 \mathrm{mg} / \mathrm{L})$. This low content assumes that the sulphate ions in these waters would therefore not come from gypsum formations. According to Banton et al (1997), their probable origin could be the oxidation of pyrite (oxidizing condition in the rainy season).

\section{Chlorides:}

The chloride ion concentration in our study area remains in compliance with WHO guidelines for drinking water and ranges from very low $(0.3 \mathrm{mg} / \mathrm{l}$ at Djangou Fandou FE) to low ( $28.3 \mathrm{mg} / \mathrm{l}$ at Timboram Hatta PC) with an average of $7.71 \mathrm{mg} / \mathrm{l}$ and a median of $6.85 \mathrm{mg} / 1$ (Table 3 and Figure 12). Low values were also found by Amadou et al (2014) in wells in the study area $(12 \mathrm{mg} / \mathrm{L}$ at Sandiré and $22 \mathrm{mg} / \mathrm{L}$ at Bonkoukou. Thus, $77.8 \%$ of the water points sampled have a content of less than $10 \mathrm{mg} / \mathrm{L}$ and $22.2 \%$ have content between 10 and $30 \mathrm{mg} / \mathrm{L}$. The origin of chlorides would probably be natural in these waters. However, these results are lower than the values found by Hamadou (2014). Indeed, the latter found chloride concentrations ranging from 7 to $83 \mathrm{mg} / \mathrm{L}$ with an average of $30.31 \mathrm{mg} / \mathrm{L}$, in the rural commune of Tagazar (Ballayara department).

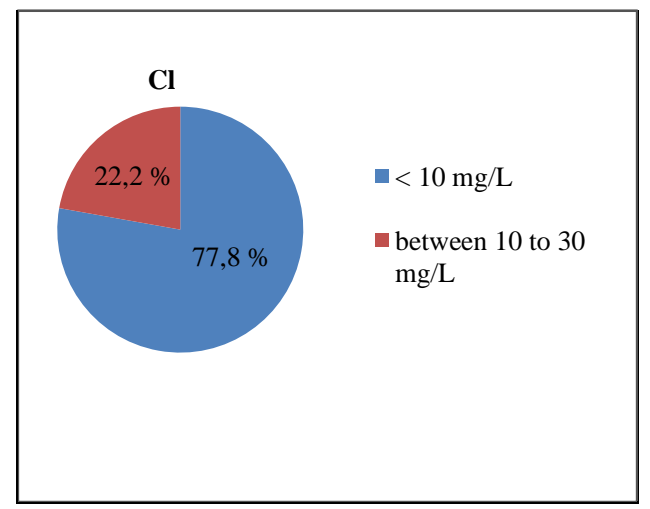

Bicarbonates carbonates:

Figure 12:-Graphical representation of $\mathrm{Cl}^{-}$

The bicarbonate content of the study area ranges from $(4.88 \mathrm{mg} / \mathrm{l}$ at Sourgo Koira PC) to low (152.5 mg/l at Timboram Hatta PC) with an average of $42.16 \mathrm{mg} / \mathrm{l}$ and a median of $27.76 \mathrm{mg} / \mathrm{l}$. This bicarbonate would be of natural origin and would come mainly from the dissolution, in water, of the $\mathrm{C}$ in the air and soil following the reaction $(\mathrm{Eq} 1)$ :

$\mathrm{CO}_{2}+\mathrm{H}_{2} \mathrm{O} \longrightarrow \mathrm{H}^{+}+\mathrm{HCO}_{3}^{-}$.

\section{Nitrates:}

The nitrate content in the study area is highly variable, ranging from $3.08 \mathrm{mg} / \mathrm{l}$ at Marakou II FE to $108.68 \mathrm{mg} / \mathrm{l}$ at Namari Bangou PC, with an average of $45.662 \mathrm{mg} / 1$ and a median of $39.6 \mathrm{mg} / \mathrm{L}$. These values are close to the results found by Hamadou (2014) in the study area (mean $51.85 \mathrm{mg} / \mathrm{L}$ and maximum $99.8 \mathrm{mg} / \mathrm{L}$ ). The mean and median values are consistent with the values found by Amadou et al (2014) in Dallol Bosso wells (42.65 mg/l at Sandiré and $43.8 \mathrm{mg} / \mathrm{L}$ at Bonkoukou). The variation in nitrate content in the waters of the study area depends on the type of structure capturing the water table, the depth captured and the activities taking place in the area.

According to Madison et al (985), the concentration of nitrates in drinking water can be classified into four categories: the first category taking into account a nitrate concentration of less than $0.2 \mathrm{mg}-\mathrm{N} / \mathrm{L}(0.86 \mathrm{mg} / \mathrm{L} \mathrm{N})$ without any human influence; the second between 0.21 and $3 \mathrm{mg}-\mathrm{N} / \mathrm{L}$ (respectively 0.93 and $13.29 \mathrm{mg} / \mathrm{L}$ of N) with possible influence of human activities; the third between 3.1 and $10 \mathrm{mg}-\mathrm{N} / \mathrm{L}$ (respectively 13.73 and $44.3 \mathrm{mg} / \mathrm{L} \mathrm{of}$ $\mathrm{N})$ with very clear influence of human activities but no apparent health impact, and finally the fourth greater than 10 mg-N/L (44.3 mg/L of N) with major human activity impact and possible health effect (Madison et al, 1985).

According to this ranking, $83.3 \%$ of the waters in the study area $(n=18)$ are polluted with nitrate following a definite influence of human activities with impacts ranging from moderate (44.4\%) to major (38.9\%); for the others (16.7\%), the influence of human activities is possible but with minor impact (Figure 13). In addition, 38.9\% of the waters have nitrate pollution with a possible effect on human health and $33.3 \%$ of the samples analyzed contain a nitrate concentration above the maximum limit of $50 \mathrm{mg} / \mathrm{L}$ set by the WHO (Figures 13 and 14); this means that the consumption of these waters is dangerous, especially for newborns (those under three months old) because they may be exposed to methemoglobinemia. 
The structures containing the highest nitrate contents are Marakou II (Auger Drilling) and Namari Bangou (PC) with 102.52 and $108.68 \mathrm{mg} / \mathrm{L}$ of $\mathrm{N}$, respectively, more than twice the maximum allowable concentration set by the WHO. Indeed, these two localities are certainly almost at the end of the Dallol, but on very sandy dune soils where agricultural and livestock activities are the main concern of the population with the use of many synthetic fertilizers and manure.

The almost widespread nitrate pollution of the groundwater table in the study area is believed to be mainly due to the infiltration of excess nitrogen from the misuse of nitrogen fertilizer products such as nitrate fertilizers and manure. The decomposition of plant and animal matter would also contribute a significant part. This nitrate pollution from leaching is favored by the sandy nature of the soil and the depth of the groundwater table. It also confirms the surface origin of the water supplying the groundwater table in the study area. Indeed, Susanne (2008) linked high nitrate concentrations to the surface origin of at least part of the groundwater supply in the urban center of Ouagadougou.

The analysis in Figure 15 shows that the very high nitrate contents were mainly recorded in cemented wells (PC) and auger drilling (FET) and that for the same locality with two different types of water points (a well/ auger drilling FET and an FE drilling), the well or FET contains much more Nitrate than the FE drilling. This suggests that these two categories of structures are the most exposed to nitrate pollution in the study area.
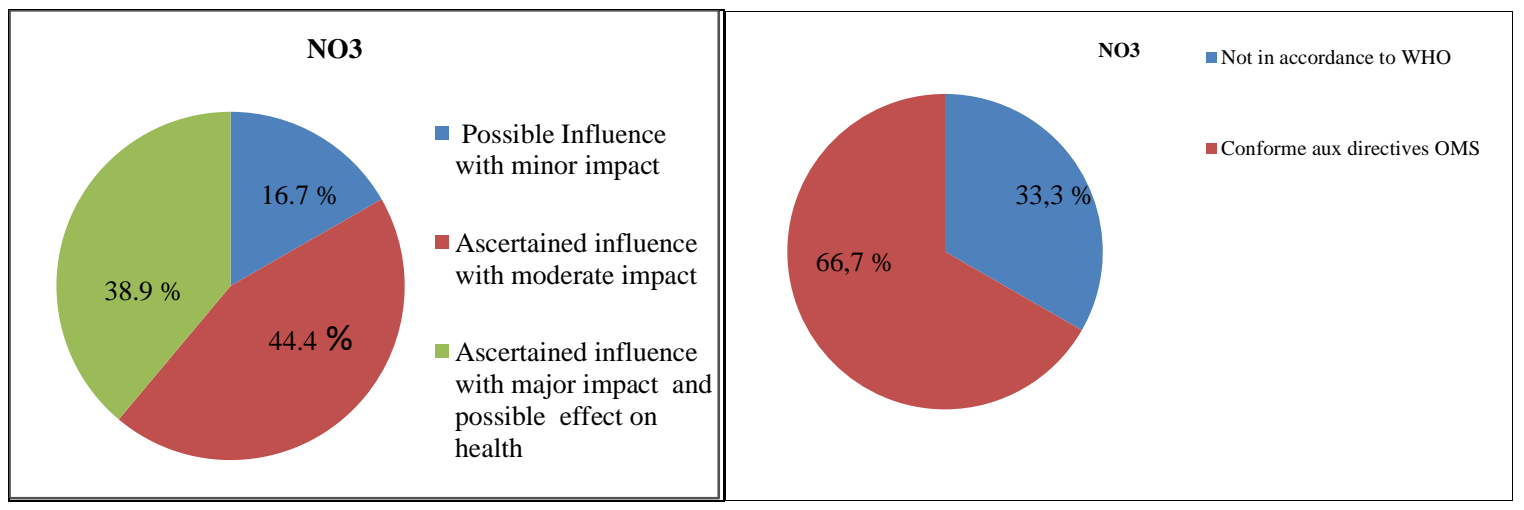

Figure 13:- $\mathrm{NO}_{3}^{-}$contents according to activities Figure 14:-Repartition of $\mathrm{NO}_{3}^{-}$according to guidelines OMS

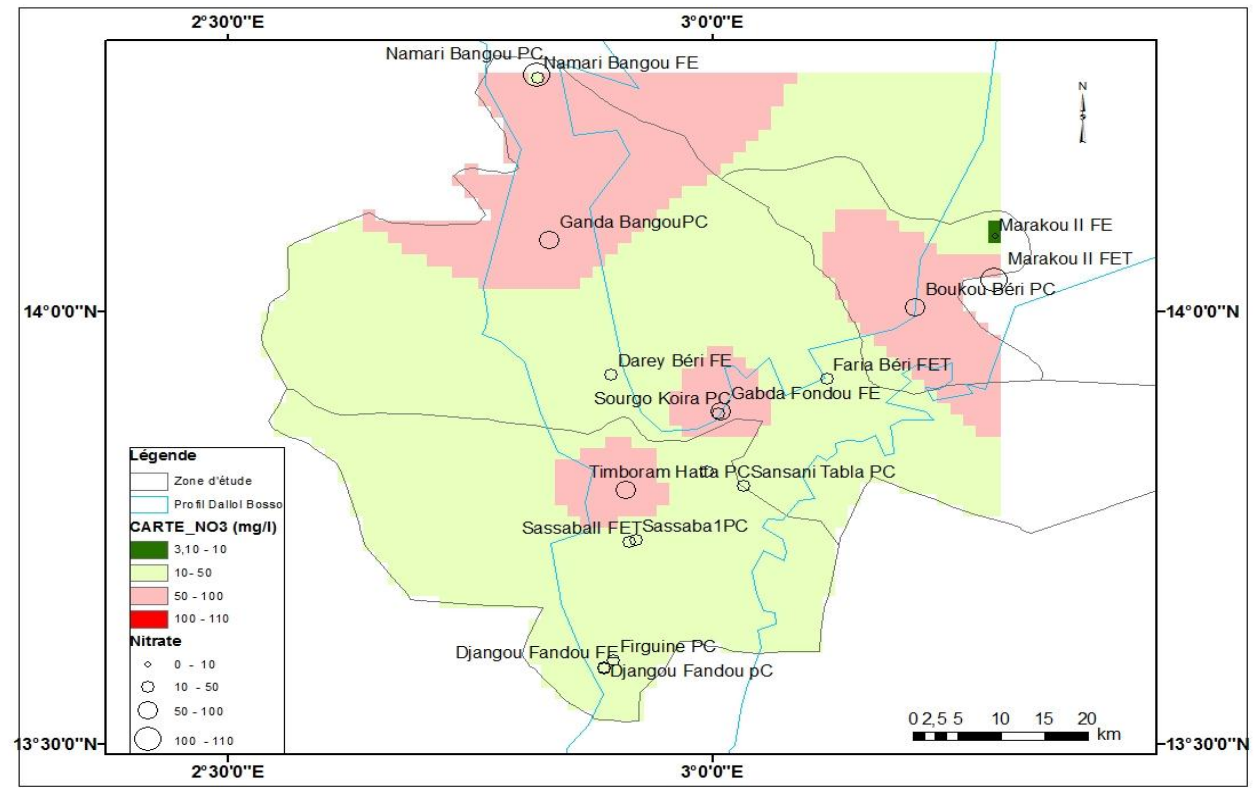

Figure 15:-Map of $\mathrm{N}$ contents in the waters of the study area. 
Other chemical parameters:

Table 4:-Statistics of other chemical parameters $(n=18)$.

\begin{tabular}{|l|l|l|l|l|l|l|l|l|}
\hline Parameters & Unit & $\begin{array}{l}\text { WHO } \\
\text { Guidelines }\end{array}$ & Mean & Median & E-type & Variance & Min & Maxi \\
\hline $\boldsymbol{F}^{-}$ & $(\mathrm{mg} / \mathrm{l})$ & 1.5 & 0.18 & 0.15 & 0.18 & 0.03 & 0.00 & 0.54 \\
\hline $\mathbf{N} O_{2}^{-}$ & $(\mathrm{mg} / \mathrm{l})$ & 0.2 et 3 & 0.151 & 0.109 & 0.139 & 0.019 & 0.016 & 0.406 \\
\hline $\mathbf{F e T}$ & $(\mathrm{mg} / \mathrm{l})$ & 0.3 & 0.15 & 0.05 & 0.25 & 0.06 & 0.00 & 0.97 \\
\hline $\mathbf{A s}$ & $(\mathrm{mg} / \mathrm{l})$ & 0.01 & 0.0000 & 0.0000 & 0.0000 & 0.0000 & 0.0000 & 0.0000 \\
\hline
\end{tabular}

\section{Fluorides :}

All samples analyzed in our study area have a low fluoride level, ranging from 0.00 to $0.54 \mathrm{mg} / \mathrm{l}$ with an average of $0.18 \mathrm{mg} / \mathrm{l}$ (Figure 16). (Amadou et al., 2014) found similar values in the study area (0.12 g/L at Sandiré and 0.34 $\mathrm{mg} / \mathrm{L}$ at Bonkoukou). This low fluoride content in the waters of the study area would expose consumers to the risk of dental caries, especially if the food they consume is also water without fluoride. Indeed, $88.88 \%$ of the samples analyzed have a fluoride content of less than $0.5 \mathrm{mg} / \mathrm{L}$.

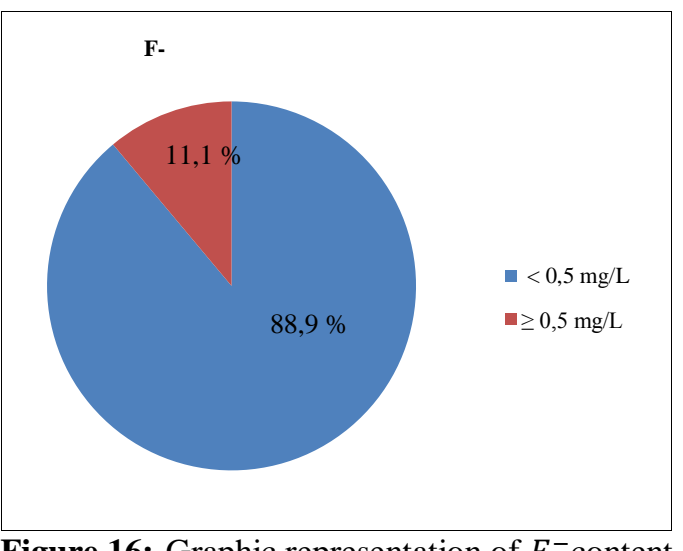

\section{Nitrites:}

Figure 16:-Graphic representation of $F^{-}$content

All samples analyzed in the study area contain nitrite. Their nitrite content ranges from $0.016 \mathrm{mg} / 1$ to $0.406 \mathrm{mg} / \mathrm{l}$, with mean and median values of $0.151 \mathrm{mg} / \mathrm{l}$ and $0.109 \mathrm{mg} / \mathrm{l}$ respectively (Figure 17). These values are lower than those found by Amadou et al (2014) in the Sandiré and Bonkoukou wells ( 0.56 and $0.99 \mathrm{mg} / \mathrm{L}$ respectively) all in the Dallol Bosso zone. This presence of nitrite in the analyzed waters implies that the nitrification process is still ongoing. It could also be due to bacterial contamination; indeed, the results of bacteriological analyzes have revealed that they are all contaminated (presence of bacteria indicating faecal contamination). For short-term exposure, all samples analyzed comply with WHO guidelines $(<3 \mathrm{mg} / \mathrm{l})$. However, five $(05)$ of them, or $27.8 \%$, have a nitrite concentration exceeding WHO guidelines $(0.2 \mathrm{mg} / \mathrm{l})$ for long-term exposure.

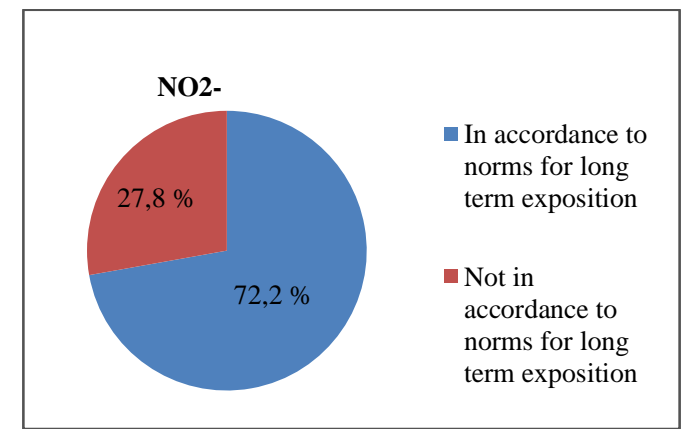

Total iron:

Figure 17:-Graphic representation of $\mathrm{NO}_{2}^{-}$content

The total iron content of our study area ranges from 0 (in Ganda Bangou PC) to $0.97 \mathrm{mg} / \mathrm{l}$ (M'Boria Banifandou) with an average of $0.15 \mathrm{mg} / \mathrm{l}$ and a median of $0.05 \mathrm{mg} / \mathrm{l}$ (Figure 18). Only three (03) water points (M'Boria Banifandou, Firgoune PC and Marakou II FET), or 16.7\%, have values above the maximum concentration of 0.3 
$\mathrm{mg} / \mathrm{L}$ set by the WHO (Figures 18 and 19). The presence of iron in the waters of our study area would therefore be essentially natural. The equipment of hydraulic structures could also contribute in places; this is the case, for example, of these three (03) water points whose content exceeds the maximum value of $0.3 \mathrm{mg} / \mathrm{L}$ set by WHO. Indeed, iron does not pose any health risk to the consumers of these waters but can affect their aesthetic quality. Iron, at concentrations usually found in natural waters, is an essential element for all living organisms in general and humans in particular (it is the main component of hemoglobin).

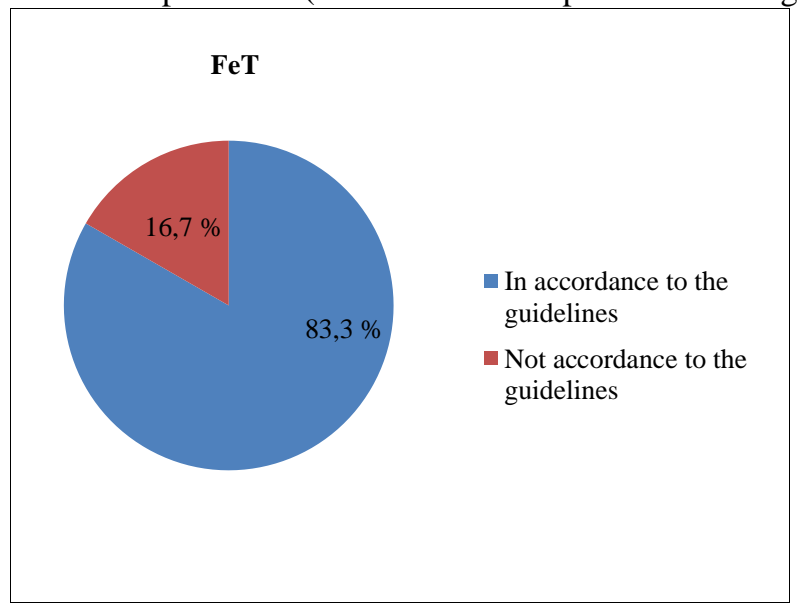

Figure 18:-Repartition of FeT content

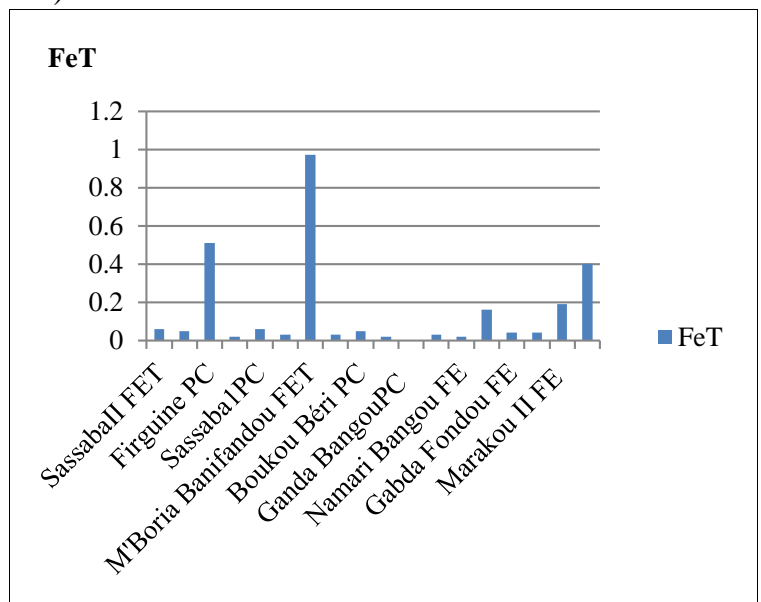

Figure 19:-Graphic representation of FeT content

\section{Arsenic:}

Arsenic is naturally present at high concentrations in groundwater in a number of countries. It is very toxic in inorganic form. Its presence in contaminated water used for drinking, food preparation and irrigation is the greatest threat to public health. Prolonged exposure to arsenic in drinking water and food can cause cancer and skin damage. It has also been attributed to developmental effects, cardiovascular disease, neurotoxicosis and diabetes. The most important measure in affected communities is to prevent exposure to arsenic by providing safe water. Arsenic is absent in all analyzed waters in the area.

\section{Microbiological parameters of water:}

In terms of hygiene, bacteriological analyzes often concern germs that act as indicators, rather than pathogenic microorganisms, without their presence necessarily constituting a risk in itself to public health. Two main types of indicators are thus distinguished: faecal contamination indicators and treatment efficiency indicators (Rodier, 2009). As part of our study, we focused on indicators of fecal contamination called coliforms (Totals and Feces).

The results of the bacteriological analyzes obtained indicate that all the waters analyzed are contaminated and the colony concentration of total coliforms (TC) varies from 150 to TNC (Too Many to Count) per $100 \mathrm{ml}$ of sample, whereas the value allowed by the WHO guidelines is 0 Colony Unit/100 ml. Indeed, more than half (10) of the samples present TNC results for total coliforms. As for faecal coliforms (FC), their concentration varies from 0 (a single sample) to $2200 \mathrm{UCF} / 100 \mathrm{ml}$ of water for 15 samples and NTC for the other 3 samples. The distribution of the different types of colonies is given in Figures 20 and 21. From a bacteriological point of view, it appears from the above that these waters are unfit for human consumption without prior treatment at the date of the analyzes. 

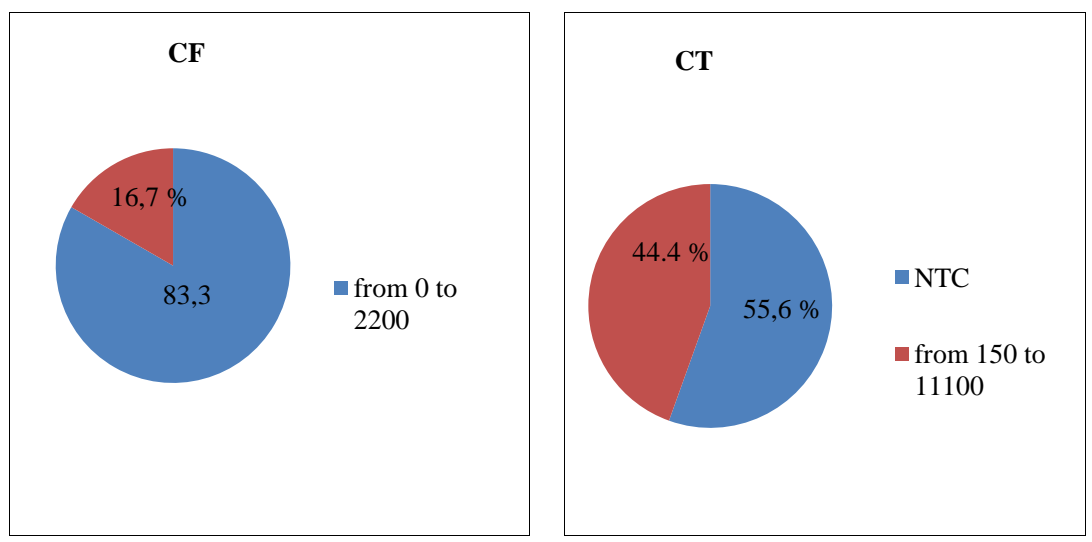

Figure 20:-Distribution of faecal coliforms Figure 21:-Distribution of total coliforms

\section{Ability of water for human consumption:}

The results of the water analyzed show that the physical and chemical quality of the water is therefore acceptable. However, some water points must be monitored more or less regularly for potassium, nitrate and nitrite ions, which seem to be limiting factors in the quality of these waters.

In addition, the result of the bacteriological analyzes show that all the samples analyzed contain germs that indicate fecal contamination. All contain total coliforms and only one (01) does not contain fecal coliforms. They therefore do not comply with WHO guidelines for drinking water (zero colony units $/ 100 \mathrm{~m}$ samples for totals and faeces). The bacteriological quality is therefore poor at the time of analysis of the samples. The water is therefore bacteriologically unfit for human consumption without prior treatment.

\section{Water suitability for irrigation:}

To determine the irrigation suitability of the water in the study area, we classified it using the Riverside Laboratory method. This method is based on electrical conductivity and sodium absorption rate or Sodium Absorption Rate (S.A.R.). We have:

S.A.R=, with, and expressed in meq/L.

The combination of these two criteria (conductivity and S.A.R.) makes it possible to define the different classes of water suitability for irrigation. Thus, Figure 22 highlights two main classes of suitability: this is the class and the class that mean that these waters are rated as excellent and good respectively. Thus, (66.7\%) of these waters belong to the class and $33.3 \%$ to the class (Figure 23); this is in accordance with the study by Armand (1985). Indeed, according to Riverside, the water in the class is safe to use for irrigation of most crops on most soils. As for those in the class, they can generally be used without particular control for the irrigation of moderately salt-tolerant plants on soils with good permeability; this is the case of the soils of the Dallol Bosso. Their texture is sandy on the surface; the clay content does not exceed 5\% while the sand content is always between 90\% and 97\% (Paquier et al, 1985).

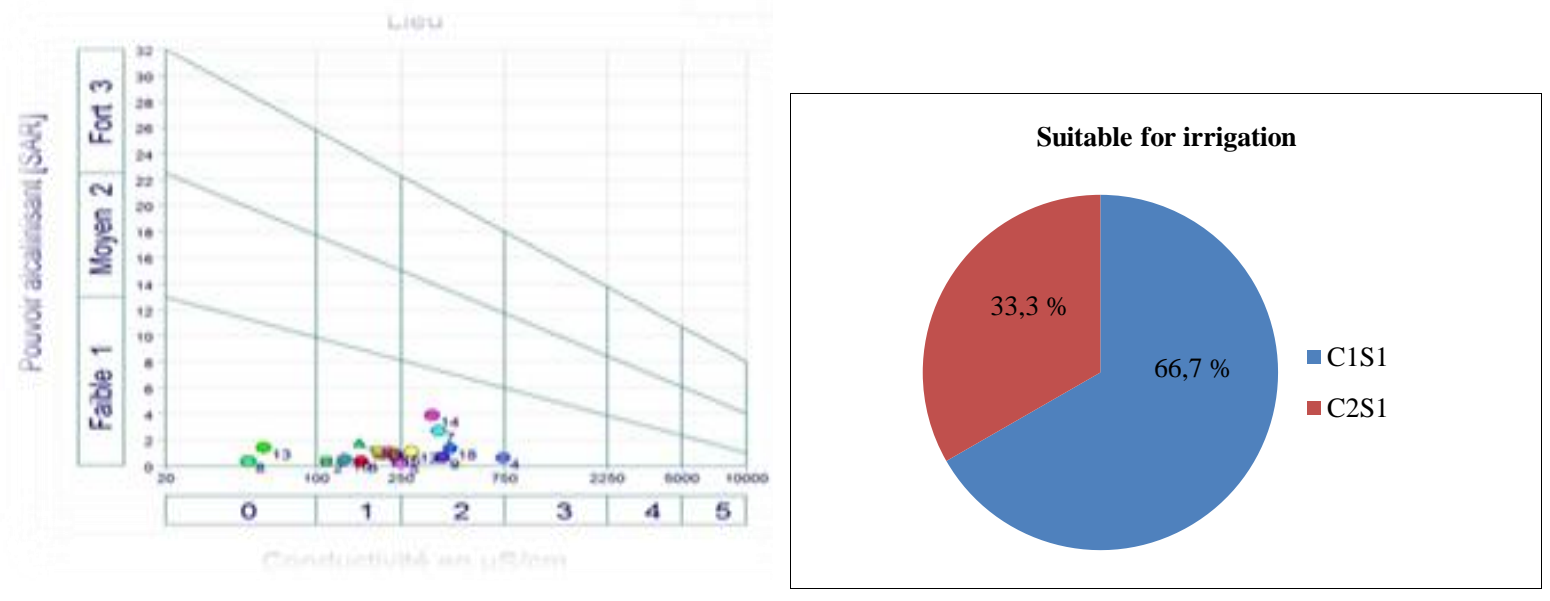


Figure 22:-Water suitability for irrigation.

Figure 23:-Distribution of irrigation suitability classes.

Vulnerability of the groundwater table in the study area:

To assess the vulnerability of the waters in our study area, we used the so-called GOD method (Bouselsal et al. 2015).

The GOD (IG) vulnerability index of the slick is calculated according to the following formula:

$I G=C_{g} \cdot C_{o} \cdot C_{d}$

\section{Where:}

$\mathrm{Cg}$ is the rating of the aquifer type parameter;

Co the rating of the lithology parameter of the unsaturated zone;

$\mathrm{Cd}$ the dimension of the depth of the slick parameter.

The GOD method identifies six (6) levels of vulnerability based on the GI index:

1. $\mathrm{GI}=0$ : no risk of pollution;

2. GI between 0 and 0.1 ; negligible vulnerability;

3. GI between 0.1 and 0.3 ; low vulnerability;

4. GI between 0.3 and 0.5 ; moderate vulnerability;

5. GI between 0.5 and 0.7 ; high vulnerability;

6. GI between 0.7 and 1 ; extreme vulnerability.

The results of the vulnerability calculations indicate that the groundwater table is vulnerable to pollution of all kinds throughout the study area. The degree of vulnerability varies from low to high and moderate. Thus, moderate vulnerability occupies $44.4 \%$, the other two (low and high) each occupy $27.8 \%$ (Figures 24 and 25). High and moderate vulnerabilities are most prevalent where the groundwater is captured by shallower and less protected hydraulic structures (cemented wells and auger drilling).

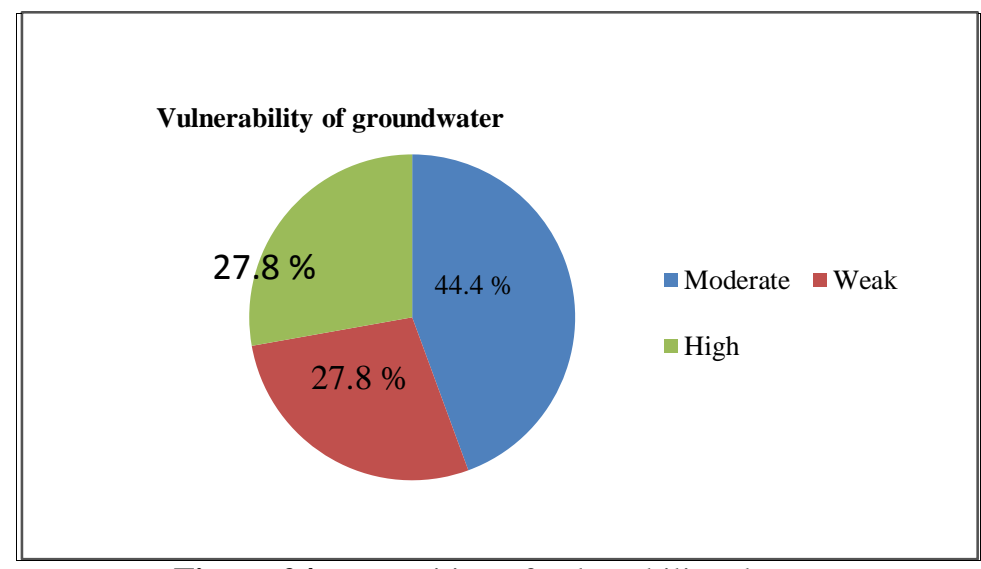

Figure 24:-Repartition of vulnerability classes 


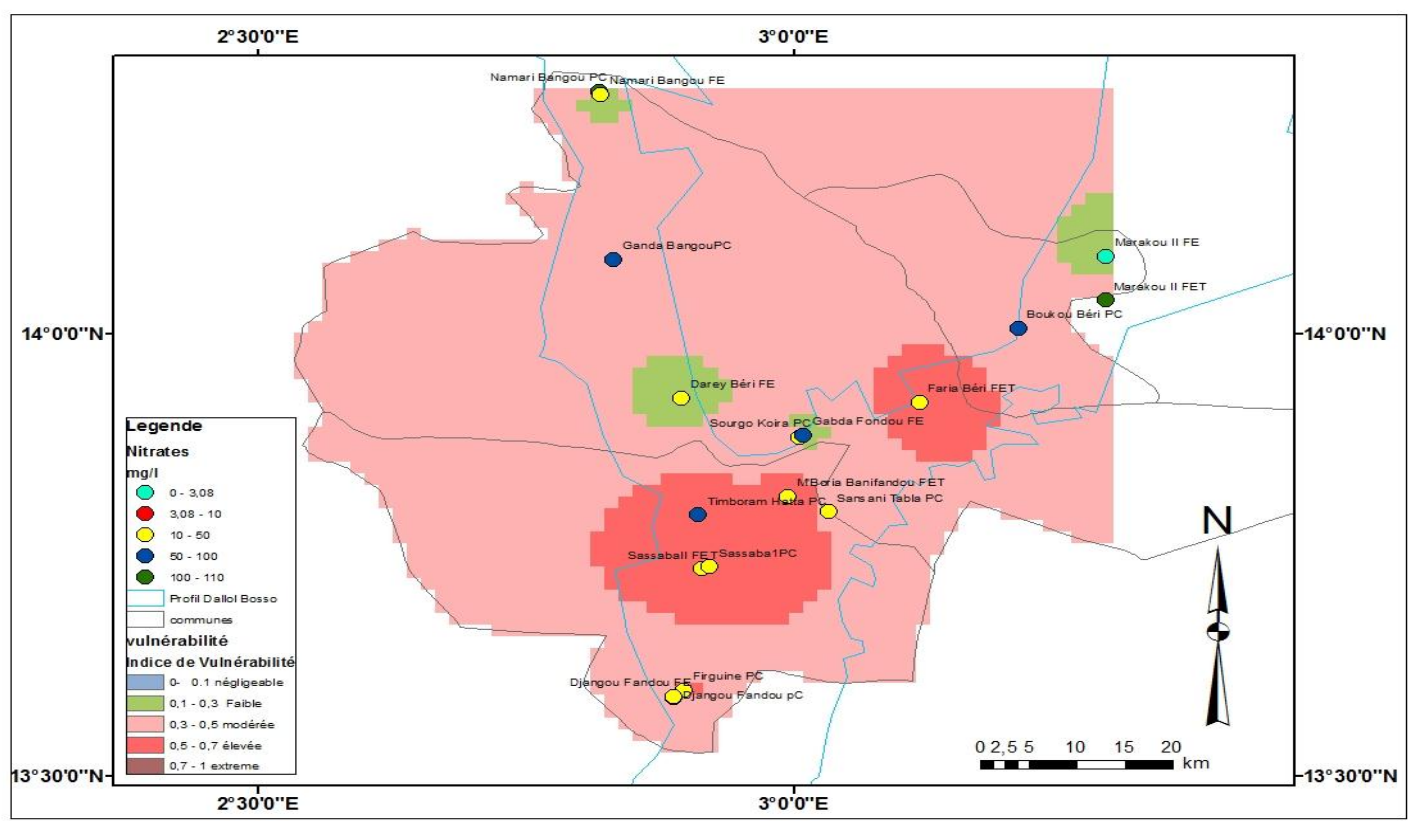

Figure 25:-Groundwater vulnerability map superimposed on nitrate contents.

\section{Conclusion:-}

The results of the physico-chemical analyzes showed that the waters studied have an acidic $\mathrm{pH}$ and are very soft to soft and low mineralized overall, with high nitrate concentration values well above WHO guidelines (33.3\%) in some localities. The risk of nitrate pollution therefore threatens the water resource in the study area. In addition, potassium contents exceeding the WHO guidelines were recorded in two water points. However, the other physicochemical parameters analyzed remain in compliance with the WHO guidelines for drinking water in most cases and the physico-chemical quality is therefore acceptable in the absence of any other recourse. As for the results of the bacteriological analyzes, they revealed a large proliferation of bacteria indicative of contamination of faecal origin (Total and Faecal Coliforms) and therefore a poor bacteriological quality.

It is therefore retained that even if the physico-chemical quality of the water analyzed is acceptable, it is bacteriologically unfit for human consumption without prior treatment.

The level of vulnerability of the slick to pollution varies from low to high. The water analyzed belongs to $66.7 \%$ of class (excellent for irrigation) and 33.3\% of class (good for irrigation).

\section{Bibliographie:-}

1. Abdou Guéro (2003): Etude des relations hydrauliques entre les nappes du complexe sédimentaire de la bordure Sud-Ouest du bassin des Iullemmeden : Approche géochimique et hydrodynamique. Thèse, Université De Paris-Sud - U.F.R. Scientifique D’Orsay, 265 p.

2. Adamou Moussa (2014): Impacts des activités agricoles sur l'état quantitatif et qualitatif de la nappe des Dallols au Niger : Cas de la nappe du Dallol Maouri dans la Région de Dosso. Mémoire de Mastère GCRN/GIRE, Centre Régional AGRHYMET. 60p.

3. Amadou H., Laouali M.S., Manzola A (2014): Analyses Physico-chimiques et Bactériologiques des eaux de trois aquifères de la Région de Tillabéry : Application des méthodes d'Analyses Statistiques Multi-Variées. Larhyss Journal, 20, 25-41.

4. Armand.C, (1985) : Schéma Directeur d'aménagement hydraulique du dallol Bosso, Etude préalable 1, 30 p.

5. Armand.C (1987) : Actualisation de l'atlas des eaux souterraines du Niger. Publication B.R.G.M.

6. Baali F. (2001): Eude hydrogéologique hydrochimique de la région karstique de Chéria N-E Algérien. Magister Univ Annaba Algerie, 100 p.

7. Banton. O, M. Lumony Bangoy (1997) : Hydrogéologie-Multiscience environnementale des eaux souterraines. Presses de l'Université du Québec /AUPELF, 159-160. 
8. Beauchamp. J (2006) : qualité et pollution des eaux souterraines, Université de Picardie Jules Verne /Jacques Beauchamp, 15 pages.

9. Boukari Ousmane, Ria Hermans, Salifou Ousseini, Hans Schoolkate (1993) : Rapport final programme d'hydraulique villageoise deuxième phase, Dosso novembre $51 \mathrm{p}$.

10. Bouselsal Boualem., Zeddouri Aziez., Belksier Mohammed (2015): Contribution de la méthode de vulnérabilité intrinsèque GOD à l'étude de la pollution de la nappe libre d'Ouargla (SE Algérie). International Journal for environment and Global Climat ISSN 2310-6743.

11. Chapman D., Kimstach V (1996): Selection of water quality Variables; Water quality assessments: a guid to the use of biota, sediments and water in environment monitoring, Chapman edition, $2^{\text {nd }}$ ed. E \& FN Spon. London, 59-126.

12. Guillaume Favreau (2000): Caractérisation et modélisation d'une nappe phréatique en hausse au Sahel : dynamique et géochimie de la dépression piézométrique naturelle du kori de Dantiandou (sud-ouest du Niger). Thèse de doctorat, Science de la Terre, Université de Paris XI, France, 239 p.

13. Hamadou Ousseyni (2014) : Contribution à l'étude de la vulnérabilité des eaux souterraines face aux activités agricoles et stratégies d'adaptation des populations : cas de la nappe phréatique du Dallol Bosso dans le département de Ballayara au Niger Mémoire de Mastère En Gestion Concertée Des Ressources Naturelles, Centre Régional Agrhymet.

14. https://fr.wikipedia.org/wiki/Dallol_Bosso ), consulté le 5 janvier 2017.

15. http://www.mddelcc.gouv.qc.ca/eau/souterraines/index.htm\#les_eaux_souterraines_et_moi, consulté le 29/01/2017)

16. Karbo.A. J.V.Loon (1992) : Etat de connaissance sur les grands systèmes aquifères du Niger ,20 p ; annexe 4 issue de l'Atelier National de Maradi intitulé «ETAT DES CONNAISSANCES SUR LES RESSOURCES EN EAU DU NIGER ».

17. Matini.L, J.M. Moutou et M.S.Kongo-Mantono (2009) : Evaluation hydrochimique des eaux souterraines en milieu urbain au Sud-Ouest de Brazzaville, Congo. Afrique SCIENCE 05 (1) (2009) 82-98.

18. Madison. R et Brunett J.D (1985): Over view of the occurrences of nitrate in groundwater of the United States US. Geological Survey, Water Suppy Paper, 2275,93-105.

19. Ministère de l'Hydraulique et de l'Assainissement (MHA) (2013) : Problématique de la qualité de l'eau au Niger. Rapport.

20. New Brunswick (2017) : General chemistry metals, Chapitre : les faits sur l'eau potable, 13 p.http://www2.gnb.ca/content/dam/gnb/Departments/hs/pdf/fr/MilieuxSains/eau/GeneralChemistry_Metalsf.pdf , consulté le 01/07/2017.

21. Nouvelle-Écosse Environnement (2008): Dans une goutte d'eau, Chapitre Calcium et magnésium,4p. : https://novascotia.ca/nse/water/docs/droponwaterFAQ-Calcium-Magnesium-Fr.pdf,consulté le 04/07/2017.

22. Nordine Nouayti, Driss Khattach, Mohamed Hilali (2015) : Evaluation de la qualité physico-chimique des eaux souterraines des nappes du Jurassique du haut bassin de Ziz (Haut Atlas central, Maroc), J. Mater. Environ. Sci. 6 (4) (2015) 1068-1081.

23. OMS (2016) : Atlas de la santé infantile et de l'environnement.

24. Ousseyni Idrissa Balkissa (2016) : Evaluation Quantitative et qualitative de la nappe alluviale de dallol Bosso : Cas des départements de Birni N'Gaouré et Falmey. Mémoire en Prospection et Gestion des Ressources en Eau Souterraine, FAST/UAM de Niamey.70 p.

25. Paquier. C, P.Vaubourg et J.L. Sabatier (1985) : Schéma Directeur d'aménagement hydraulique du dallol Bosso, synthèse , $30 \mathrm{p}$.

26. Rodier J. et al (2009) : L'analyse de l'eau, 9e édition. DUNOD (éditeur), Paris, France.1579 p.

27. Société Générale des Techniques Hydro-Agricoles (SOGETHA) (1962) :.Monographie et possibilités de développement agricole de la vallée du Dallol Bosso ,65 p.

28. Suzanne Ouandaogo/Yameogo (2008) : Ressources En Eau Souterraine du Centre Urbain de Ouagadougou au Burkina Faso : Qualité et Vulnérabilité. Thèse de Doctorat en Sciences (spécialité Hydrogéologie).Université d'Avignon et des Pays de Vaucluse.206 p. 